\section{Calotes versicolor (Squamata: Agamidae)—A New Invasive Squamate for Borneo}

\author{
INDRANEIL DAS*1, JOSEPH K. \\ CHARLES $^{2}$, AND DAVID S. EDWARDS ${ }^{2}$
}

${ }^{1}$ Institute of Biodiversity and Environmental Conservation, Universiti Malaysia Sarawak, 94300 Kota Samarahan, Sarawak, MALAYSIA

${ }^{2}$ Department of Biology, Universiti Brunei Darussalam, Jalan Tunku Link, Gadong, Bandar Seri Begawan 2028, BRUNEI DARUSSALAM

\begin{abstract}
Calotes versicolor, hitherto known from the Asian mainland, from eastern Iran, across the Indian Subcontinent, to Indo-China and Indo-Malaya, with several naturalized populations in both the New and Old Worlds, is here reported for the first time from Borneo (from Brunei Darussalam, in the northwestern part of the island). The ecological consequences of invasion of this agamid lizard, reported from studies elsewhere, include competition with other saurian species, and predation on local invertebrates and small vertebrates, with undesirable effects in terms of conservation of the local biota.
\end{abstract}

Key words: Agamidae; Borneo; Brunei Darussalam; Calotes versicolor; Invasive Species

Calotes versicolor (Daudin, 1802), as presently constituted, is a widespread species of the family Agamidae, known from eastern Iran (Anderson, 1999), Afghanistan (Clark et al., 1969), eastwards to China and south to the Malay Peninsula (Smith, 1935; Auffenberg and Rehman, 1993; Zug et al., 2006). Apart from its natural distribution, this diurnal and conspicuous species has been reported as

\footnotetext{
* Corresponding author.

E-mail address: hamadryad2004@hotmail.com
}

being naturalized in a number of offshore islands, as well as continental localities, including Florida in the Southeastern U.S.A. (Enge and Krysko, 2004), Réunion and Mauritius in the Mascarene Archipelago (Henkel and Schmidt, 2000: 149-150), Diego Garcia of the British Indian Ocean Territory (Kraus, 2003), and the Andaman Islands of India (Biswas and Sanyal, 1980; Das, 1999; see Lever [2003] for review). It has not been reported from the island of Borneo (Das, 2004, 2007), although de Rooij (1915) reported it from the adjacent Sundaic island of Sumatra, and Vinson (1870) mentioned its introduction into Mauritius from individuals originating from Java. A single record from Sumatra was given in de Rooij (1915) (as from "Oleh-leh in Atjeh" [corresponding to Olehleh, $05^{\circ} 34.60^{\prime} \mathrm{N}, 95^{\circ} 17.60^{\prime} \mathrm{E}$, Daerah Istimewa Aceh, Republic of Indonesia], in the extreme north of the island). Several years later, three additional specimens were reported from the same general area (" $60 \mathrm{~km}$.- - au Nord de Medan", the city of Medan being located at $03^{\circ} 34.60^{\prime} \mathrm{N}, 98^{\circ} 40.00^{\prime} \mathrm{E}$, in Sumatera Utara Propinsi, Republic of Indonesia) by Brongersma (1931). These suggest an introduction of $C$. versicolor from mainland Southeast Asia, presumably from the western coast of Peninsular Malaysia, which is located ca. $65 \mathrm{~km}$ northeast of Sumatra at the narrowest point of the Straits of Melaka, along and across which maritime trade has been so active.

The earliest herpetological work for the Malay Peninsula (Cantor, 1847) did not record C. versicolor, although it included an extensive list of herpetological species. A century ago, the distribution of the species extended only to the northern part of the Malay Peninsula. Boulenger (1912), in describing its local distribution, wrote that the species was "Very abundant in Trang, the Patani States, and in Upper Perak, but rare in South Perak, and does not seem to extend to the southern portion of the Malay Peninsula". More recent papers on the fauna of the southern Malay Peninsula do not report this species. Sworder (1925) did not include $C$. versicolor in the 